\title{
Текстура поверхности монокристаллического кремния, окисленного под тонким слоем $\mathrm{V}_{2} \mathrm{O}_{5}$
}

\author{
(C) С.Е. Никитин ${ }^{1}$, А.В. Нащекин ${ }^{1}$, Е.Е. Терукова ${ }^{1,2}$, И.Н. Трапезникова ${ }^{1}$, А.В. Бобыль ${ }^{1}$, В.Н. Вербицкий ${ }^{1}$ \\ ${ }^{1}$ Физико-технический институт им. А.Ф. Иоффе Российской академии наук, \\ 194021 Санкт-Петербург, Россия \\ ${ }^{2}$ ООО „НТЦ тонкопленочных технологий в энергетике при ФТИ им. А.Ф. Иофрфе“, \\ 194064 Санкт-Петербург, Россия \\ E-mail: nikitin@mail.ioffe.ru
}

(Получена 25 апреля 2016 г. Принята к печати 4 мая 2016 г.)

Исследован процесс текстурирования поверхности монокристаллического кремния, окисленного под слоем $\mathrm{V}_{2} \mathrm{O}_{5}$. Интенсивное окисление кремния на границе $\mathrm{Si}-\mathrm{V}_{2} \mathrm{O}_{5}$ начинается при температуре $903 \mathrm{~K}$, что на $200 \mathrm{~K}$ ниже, чем при термическом окислении кремния в атмосфере кислорода. На границе $\mathrm{V}_{2} \mathrm{O}_{5}-\mathrm{Si}$ образуется слой диоксида кремния толщиной от 30-50нм с включениями $\mathrm{SiO}_{2}$ в кремний глубиной до 400 нм. Найдено значение коэффициента диффузии атомарного кислорода при $903 \mathrm{~K}$ через слой диоксида кремния $\left(D \geq 2 \cdot 10^{-15} \mathrm{~cm}^{2} \cdot \mathrm{c}^{-1}\right)$. Предложена модель низкотемпературного окисления кремния, основанная на диффузии атомарного кислорода из $\mathrm{V}_{2} \mathrm{O}_{5}$ через слой $\mathrm{SiO}_{2}$ к кремнию и возникновении преципитатов $\mathrm{SiO}_{x}$ в кремнии. После удаления слоев $\mathrm{V}_{2} \mathrm{O}_{5}$ и диоксида кремния на поверхности кремния образуется текстура, интенсивно рассеивающая свет в области длин волн $300-550$ нм, что важно для текстурирования фронтальной и тыльной поверхностей солнечных фотопреобразователей.

DOI: $10.21883 /$ FTP.2017.01.44004.8292

Солнечные фотоэлектрические преобразователи $(Ф Э П)$ на основе гетеропереходов $(c-\mathrm{Si})-(a-\mathrm{Si}: \mathrm{H})$ являются перспективными с точки зрения соотношения коэффициента полезного действия и стоимости. Такие ФЭП носят сокращенное англоязычное наименование HIT (heterojunction with intrinsic thin-layer solar cell) $[1,2]$. Одним из способов увеличения эффективности таких ФЭП является использование текстурированных слоев, расположенных на поверхности монокристаллической кремниевой пластины. Назначение этих слоев состоит в увеличении поглощения излучения в активных кремниевых слоях ( $p-n$-переходах) за счет многократных отражений от стенок текстуры. Все ФЭП имеют на фронтальной поверхности прозрачный проводящий электрод (ППЭ), отделенный тонким слоем полимера от герметизирующей пластины. В качестве ППЭ обычно используются слои $\mathrm{ZnO}$, легированного алюминием $(\mathrm{ZnO}: \mathrm{Al})$, с коэффициентом преломления в диапазоне от 2 до 2.2. Коэффициент преломления полимерного слоя равен 1.41 . Если свет, отраженный от поверхности кремния, падает на границу ППЭ-полимер под углами, близкими к углу или бо́льшими угла полного внутреннего отражения, то излучение вновь возвращается в кремниевые активные слои. Для максимального увеличения такого эффекта необходимо увеличивать рассеянное (диффузное) отражение излучения от поверхности кремния, что требует создания шероховатостей $\mathrm{c}$ размерами, близкими к длинам волн видимого света. Показателем эффективности рассеяния поверхностью отраженного света с длиной волны $\lambda$ служит коэффициент диффузного отражения света (в англоязычной литературе - Hazefactor, $H(\lambda))$, который представляет собой отношение потока диффузно отраженного света, $R_{\text {diff }}(\lambda)$, к полному потоку отраженного света, $R_{\text {full }}(\lambda): H(\lambda)=R_{\text {diff }} / R_{\text {full }}$.
Наиболее распространенными способами текстурирования поверхности кремния являются анизотропное жидкостное и плазменное травление, а также фотолитография с последующим жидкостным травлением. Анизотропное жидкостное травление и травление в плазме позволяют обрабатывать большие поверхности кремния и получать неупорядоченную пирамидальную текстуру с размерами от 1 до 3-4мкм [3-6]. Фотолитографические методы позволяют получать упорядоченные и неупорядоченные структуры с очень большим разбросом размеров, но они дороги и не обеспечивают высокой производительности. Существует также возможность создания текстур на большой поверхности кремния путем его неоднородного окисления в результате твердофазного взаимодействия кремния и предельного оксида переходного металла с последующим растворением оксида кремния и оксида переходного металла в плавиковой кислоте. Для создания текстур на поверхности кремния необходимо, чтобы оксид переходного металла не испарялся, не разлагался при нагреве и легко растворялся в плавиковой и других кислотах. Необходимо также, чтобы продукты взаимодействия кремния и оксида переходного металла легко удалялись с помощью традиционных химических обработок.

Рассмотрим тонкий слой предельного оксида переходного металла, находящегося на поверхности кремния. Переходный металл имеет несколько степеней окисления: $+n,+(n-1),+(n-2) \ldots(+n-$ максимальная степень окисления, характерная для предельного оксида). Необходимо, чтобы переходный металл мог легко переходить из одной степени окисления в другую. При повышенных температурах начинается взаимодействие оксида переходного металла и кремния, которое может приводить к окислению кремния и восстановлению 
металла в оксиде. Полное восстановление оксида до металла необязательно, достаточно чтобы металл изменил свое валентное состояние от $\mathrm{Me}^{+n}$ до $\mathrm{Me}^{+(n-1)}$. Для этого необходимо, чтобы изобарно-изотермический потенциал $(\Delta G)$ этой реакции был отрицательным. Среди этих оксидов нами был выбран предельный оксид ванадия $\mathrm{V}_{2} \mathrm{O}_{5}$. Этот выбор обусловлен тем, что ванадий кроме предельного оксида $\left(\mathrm{V}^{+5}\right)$ образует ряд оксидов со степенями окисления $+4,+3,+2$. Известны технологические эксперименты, где $\mathrm{V}_{2} \mathrm{O}_{5}$ использовался в качестве хемостимулятора (катализатора) окисления полупроводниковых материалов [7]. При повышенных температурах на границе $\mathrm{Si}-\mathrm{V}_{2} \mathrm{O}_{5}$ могут происходить реакции с окислением кремния и восстановлением ванадия. В частности, реакция восстановления $\mathrm{V}^{+5}$ до $\mathrm{V}^{+4}$ выглядит следующим образом:

$$
\mathrm{Si}+2 \mathrm{~V}_{2} \mathrm{O}_{5}=\mathrm{SiO}_{2}+4 \mathrm{VO}_{2} .
$$

Энергия Гиббса $(\Delta G)$ этой реакции при 903-923 K отрицательна, $\Delta G \sim(-680$ кДж/моль $)$, и следовательно, эта реакция может осуществляться. Аналогично могут осуществляться и реакции, где ванадий меняет степень окисления до $+3,+2$ [8]. Особенностью окисления кремния является то, что рост пленки $\mathrm{SiO}_{2}$ происходит в глубь объема кристалла кремния. С увеличением толщины слоя $\mathrm{SiO}_{2}$ зависимость толщины пленки от времени определяется диффузией кислорода через слой диоксида кремния к границе $\mathrm{SiO}_{2}-\mathrm{Si}$ и выражается параболической зависимостью от времени. Если процесс происходит в кислородсодержащей атмосфере, то низшие оксиды ванадия, образующиеся на границе $\mathrm{V}_{2} \mathrm{O}_{5}-\mathrm{Si}$ по реакции (1), будут вновь окисляться до предельного оксида (регенерация) за счет диффузии кислорода через пленку $\mathrm{V}_{2} \mathrm{O}_{5}$ и реакция (1) будет возобновляться. В дальнейшем зависимость толщины оксида от времени становится логарифмической и рост пленки прекращается.

\section{1. Методика эксперимента}

В экспериментах использовались стандартные полированные пластины монокристаллического кремния, выращенного по методу Чохральского (Cz-кремний, КДБ-10), с содержанием кислорода $\sim 10^{18} \mathrm{~cm}^{-3}$. Для получения слоев $\mathrm{V}_{2} \mathrm{O}_{5}$ была использована двухстадийная методика. На первой стадии методом термического вакуумного испарения на поверхность пластин монокристаллического кремния осаждался слой металлического ванадия толщиной 70-80 нм, который в дальнейшем окислялся до предельного пентоксида ванадия при температуре $723 \mathrm{~K}$ в кислороде или на воздухе в течение 1 ч. Далее проводился отжиг полученной структуры при температуре $903 \mathrm{~K}$ в кислороде или на воздухе в течение 1 ч. Толщина и структура полученных слоев определялись с помощью сканирующего электронного микроскопа JSM $7001 \mathrm{~F}$ (Jeol, Япония). В результате окисления при $723 \mathrm{~K}$ на поверхности кремния получался слой $\mathrm{V}_{2} \mathrm{O}_{5}$ толщиной $\sim 200$ нм, имеющий столбчатую структуру (рис. 1 ). Из рис. 1 видно, что после первой стадии на границе кремния и $\mathrm{V}_{2} \mathrm{O}_{5}$ пограничный слой отсутствует. Слой пентоксида ванадия растворялся в концентрированной соляной кислоте, затем образец промывался в этаноле и деионизованной воде. После этой обработки поверхность кремния была совершенно гладкой, а элементный анализ показал, что поверхность не содержала никаких элементов, кроме кремния и следов кислорода. Следовательно, на первой стадии заметное взаимодействие $\mathrm{V}_{2} \mathrm{O}_{5}$ и кремния отсутствует.

Стехиометричность поверхностной пленки $\mathrm{V}_{2} \mathrm{O}_{5}$ определялась с помощью методики комбинационного рассеяния света. Для этих исследований использовался спектрометр LabRamHR800. Спектр комбинационного рассеяния пленки $\mathrm{V}_{2} \mathrm{O}_{5}$ (рис. 2), находящейся на по-

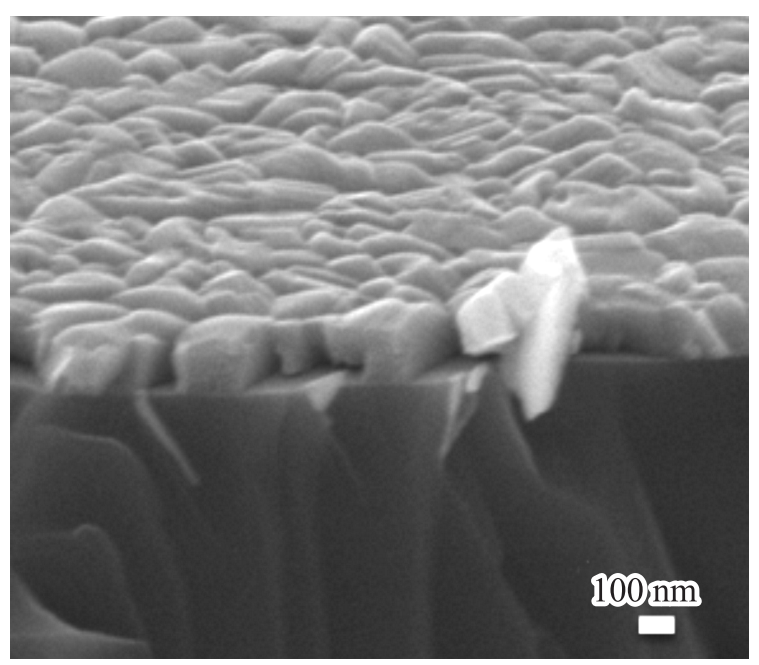

Рис. 1. СЭМ-изображение скола подложки кремния со слоем $\mathrm{V}_{2} \mathrm{O}_{5}$ на поверхности после окисления ванадия при $723 \mathrm{~K}$. Светлая область - слой $\mathrm{V}_{2} \mathrm{O}_{5}$.

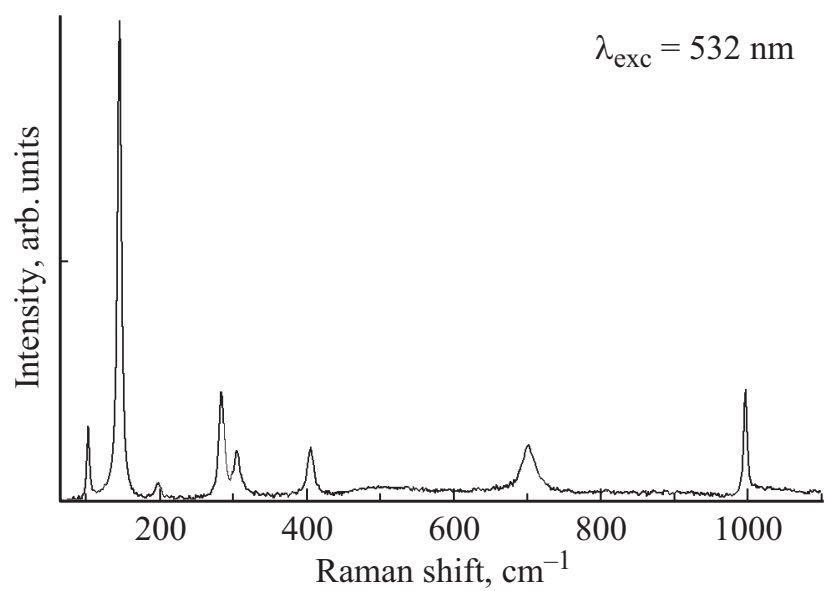

Рис. 2. Спектры комбинационного рассеяния пленки $\mathrm{V}_{2} \mathrm{O}_{5}$ при комнатной температуре и возбуждении излучением с длиной волны $\lambda_{\mathrm{exc}}=532 \mathrm{HM}$. 


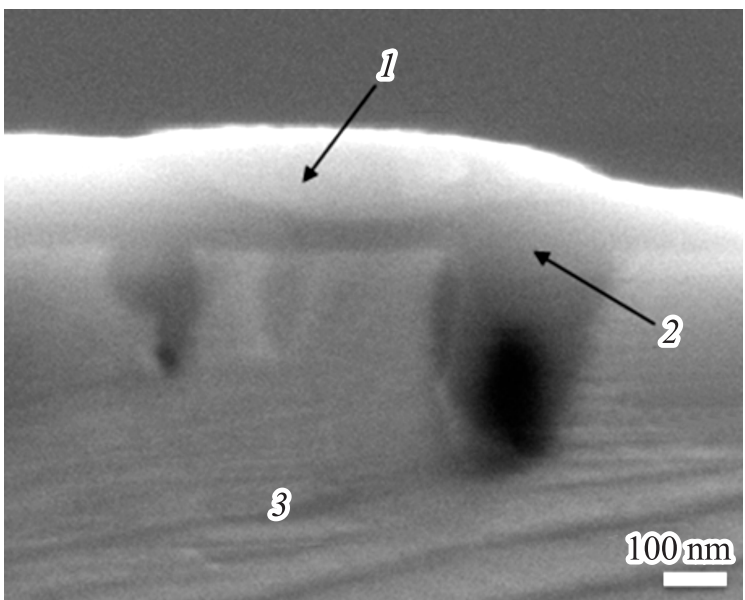

Pис. 3. СЭМ-изображение скола структуры $\mathrm{Si}-\mathrm{V}_{2} \mathrm{O}_{5}$ после отжига при $903 \mathrm{~K}$ в течение 1 ч. 1 - поверхностный слой $\mathrm{V}_{2} \mathrm{O}_{5}, 2$ - слои $\mathrm{SiO}_{2}, 3$ - кремниевая подложка.

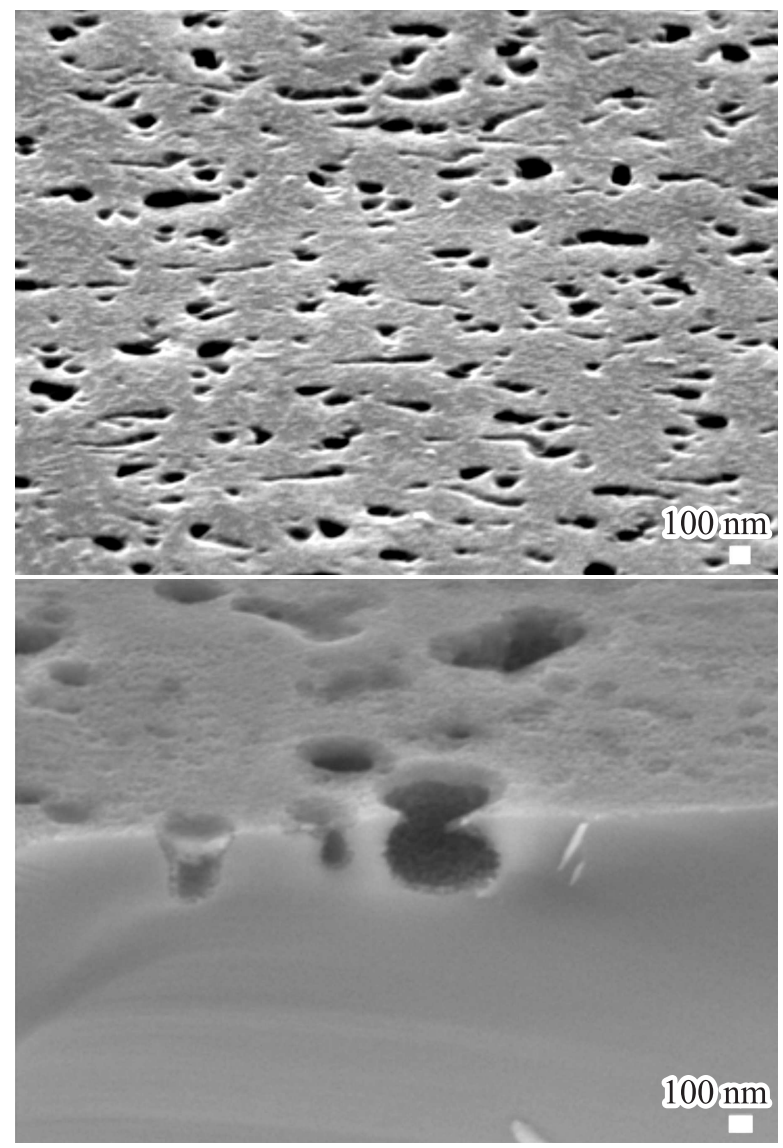

Pис. 4. СЭМ-изображение поверхности кремния (вверху) и скола поверхности кремния (внизу) после обработки в плавиковой кислоте.

верхности кремния, после отжига при $723 \mathrm{~K}$ совпадает с литературными данными [9]. Эти спектры после отжига при $903 \mathrm{~K}$ оставались без изменений, что указывает на сохранение химического состава плен- ки $\mathrm{V}_{2} \mathrm{O}_{5}$. Электронно-микроскопическое исследование сколов структуры, полученной при $903 \mathrm{~K}$, показало, что на этой стадии отжига происходит интенсивное взаимодействие на границе $\mathrm{V}_{2} \mathrm{O}_{5}$ и кремния (рис. 3). $\mathrm{B}$ результате этого взаимодействия в соответствии с реакцией (1) на границе $\mathrm{Si}-\mathrm{V}_{2} \mathrm{O}_{5}$ образуется слой оксида кремния. Электронно-микроскопическое исследование показывает также, что слой оксида кремния, образовавшийся при $903 \mathrm{~K}$, имеет существенный разброс по толщине, находящейся в пределах от 30 до 400 нм. Можно выделить плоские участки этого слоя толщиной 30-50 нм, между которыми находятся глубокие включения (до $400 \mathrm{Hм}$ ). Увеличение времени отжига $>1$ ч при $903 \mathrm{~K}$ не приводило к увеличению толщины образующегося слоя. Верхний слой пентоксида ванадия растворялся в соляной кислоте, а пограничный слой в этой кислоте не растворялся. После обработки в 40\%-й плавиковой кислоте легко удалялся и этот слой, откуда следует, что этот слой представляет собой оксид кремния, близкий по составу к $\mathrm{SiO}_{2}$. В результате растворения слоя диоксида кремния на поверхности кремния образуется текстурированный слой с очень своеобразной геометрией (рис. 4). Как видно из микроизображений, поверхность состоит из многочисленных вогнутых сфероидов с различными эксцентриситетами с размерами от 100 до $500 \mathrm{Hм} \mathrm{и} \mathrm{глубиной} \mathrm{до} 400 \mathrm{Hм}$, которые разделены между собой относительно гладкими областями с размерами 300-1000 нм. Исследования элементного состава показали, что на этой поверхности нет никаких веществ, кроме кремния. Текстурированная поверхность кремния обладала ярко выраженными поглощающими и рассеивающими свойствами в области длин волн видимого диапазона. Измерение спектров отражения проводилось на спектрофотометре Cary 5000 UV-Vis-NIR. Исходная (полированная) поверхность кремния имела пренебрежимо малое диффузное рассеяние, $H(\lambda) \leq 1 \%$ в области длин волн 300-1000 нм. После текстурирования кремния наибольшие изменения в отражении наблюдались в области длин волн 300-500 нм (рис. 5), где полное отражение, $R_{\text {full }}(\lambda)$, уменьшалось в 1.7-1.33 раза. Диффузное отражение, $R_{\text {diff }}(\lambda)$, увеличилось до $\sim 9 \%$ при 380 нм и $\sim 6 \%$ на длине волны 500 нм. Следовательно, $H(380$ нм $) \approx 24 \%$, $H(500 \mathrm{Hм}) \approx 17 \%$. Наибольшее рассеяние света происходит, когда размеры неоднородностей и длина волны света близки. Можно сделать вывод, что большая часть вогнутых сфероидов, образующих текстуру на поверхности кремниевой пластины, имеет характерные размеры, находящиеся в области $300-500 \mathrm{Hм}$, что совпадает с данными электронно-микроскопического исследования.

Известно, что кислород при температурах $<573 \mathrm{~K}$ находится в Cz-кремнии в виде пересыщенного раствора. Термические обработки при температурах > $703 \mathrm{~K}$ приводят к распаду пересышенного раствора и появлению в объеме кремния микроскопических преципитатов аморфного субоксида кремния $a-\mathrm{SiO}_{x}[10]$. Для подтверждения образования преципитатов $\mathrm{SiO}_{x}$ в объеме 


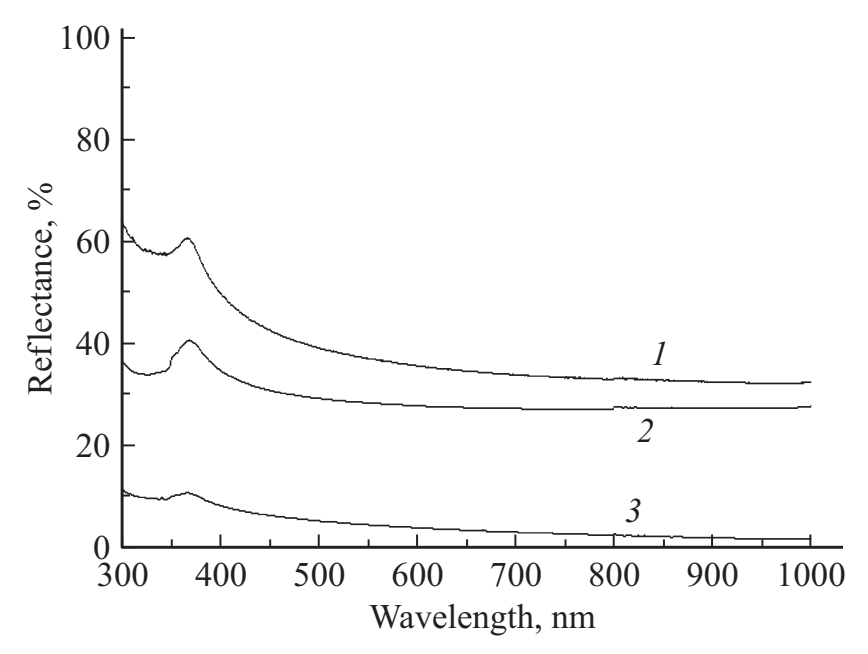

Pис. 5. Спектры отражения поверхности кремния: 1 - полное отражение от полированной поверхности кремния, $2-$ полное отражение от текстурированной поверхности кремния, 3 - диффузное отражение от текстурированной поверхности кремния.

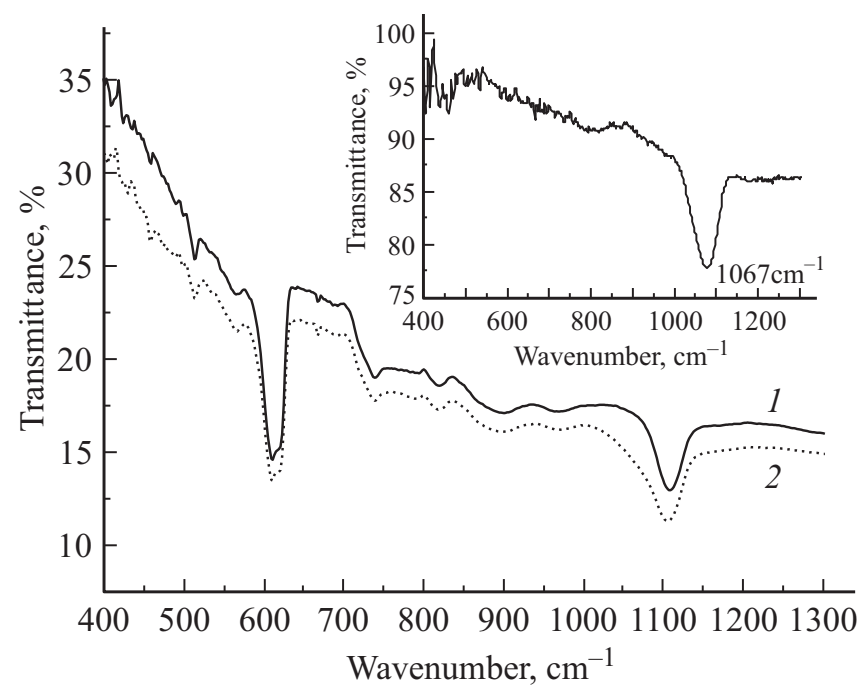

Рис. 6. Спектры пропускания исходной пластины кремния до (1) и после (2) двухступенчатого отжига при $723 \mathrm{~K} / 1$ ч $+903 \mathrm{~K} / 1$ ч. На вставке - спектр пропускания отожженного образца относительно исходного.

кремния в процессе термических обработок были измерены инфракрасные (ИК) спектры исходных пластин кремния и пластин кремния после отжига в температурных режимах, идентичных использованным для приготовления образцов. Двухступенчатый отжиг в режиме $723 \mathrm{~K} / 1$ ч $+903 \mathrm{~K} / 1$ ч осуществлялся в атмосфере высокочистого азота. Спектры снимались с помощью ИК фурье-спектрометра FTIR Shimadzu-8400s в диапазоне $400-4000 \mathrm{~cm}^{-1}$ (рис. 6). Для исходных пластин кремния характерно наличие сильной полосы поглощения с максимумом в области $1107 \mathrm{~cm}^{-1}$, связанной с асимметричными валентными колебаниями связей $\mathrm{Si}-\mathrm{O}-\mathrm{Si}$ (мода растяжения). Концентрация кислорода в исход- ных образцах $\sim 1.2 \cdot 10^{18} \mathrm{~cm}^{-3}$. После двухступенчатого отжига в атмосфере высокочистого азота полоса поглощения уширяется, максимум ее немного смещается. Спектр пропускания отожженного образца относительно исходного имеет четкий минимум при $1067 \mathrm{~cm}^{-1}$, что подтверждает появление в кремниевых пластинах после отжига в инертной атмосфере аморфного субоксида кремния $\alpha-\mathrm{SiO}_{x}(x \leq 2)$. Далее будет показано, что образование преципитатов $\mathrm{SiO}_{x}$ в объеме кремния существенно влияет на однородность окисления кремния под слоем $\mathrm{V}_{2} \mathrm{O}_{5}$.

Проведенные эксперименты показали, что при отжиге образцов интенсивное окисление кремния на границе $\mathrm{Si}-\mathrm{V}_{2} \mathrm{O}_{5}$ начинается при температуре $903 \mathrm{~K}$, что существенно ниже, чем при обычном термическом окислении в кислородсодержащей атмосфере. Слой оксида кремния имеет существенный разброс по толщине (рис. 3) с включениями глубиной до 400 нм. В промежутках между глубокими включениями находятся плоские области диоксида кремния толщиной 30-50 нм, что в 5-6 раз больше, чем толщина $\mathrm{SiO}_{2}$, образующегося при термическом окислении кремния в атмосфере кислорода в аналогичных температурно-временны́х режимах.

Полученные результаты позволяют сделать выводы о механизме ускоренного окисления кремния под слоем $\mathrm{V}_{2} \mathrm{O}_{5}$. Обычно поверхность кремния перед окислением уже покрыта тонким слоем оксида и по мере его роста все более существенную роль начинает играть диффузия кислорода к границе $\mathrm{SiO}_{2}-\mathrm{Si}$. На этой стадии зависимость толщины пленки от времени определяется диффузией кислорода через слой диоксида кремния и выражается параболической зависимостью от времени. В дальнейшем зависимость толщины оксида от времени становится логарифмической и рост пленки прекращается. Поэтому основной вклад в зависимость толщины пленки $\mathrm{SiO}_{2}$ от времени вносит параболический участок. В простейшем случае одномерной диффузии кислорода толщина слоя $\mathrm{SiO}_{2}(h)$ выражается формулой

$$
h=\sqrt{2 D \tau},
$$

где $D-$ коэффициент диффузии кислорода, $\tau-$ время. Подставив в (2) измеренные толщины слоя оксида кремния, образовавшегося за 1 ч на различных участках поверхности кремния при температуре $903 \mathrm{~K}$, можно оценить значения коэффициента диффузии кислорода на этих участках. Для плоских участков $(h \approx 40 \mathrm{Hм})$ величина коэффициента диффузии $D_{1} \approx 2 \cdot 10^{-15} \mathrm{~cm}^{2} \cdot \mathrm{c}^{-1}$. Для участков поверхности кремния с глубокими включениями диоксида кремния $(h \approx 400 \mathrm{Hм})$ вычисленный коэффициент диффузии кислорода намного больше, $D_{2} \approx 2 \cdot 10^{-13} \mathrm{~cm}^{2} \cdot \mathrm{c}^{-1}$. Сравним эти результаты с параметрами термического окисления кремния в сухом кислороде при тех же температурах. Толщина слоя оксида кремния $h$, образующегося при $973 \mathrm{~K}$ в атмосфере сухого кислорода за 17 ч, $\leq 10 \mathrm{Hм}$, и оценочное значение коэффициента диффузии кислорода составляет $D_{\text {dry }} \approx 1 \cdot 10^{-17} \mathrm{~cm}^{2} \cdot \mathrm{c}^{-1}[11]$. Большое различие в 
коэффициентах диффузии кислорода указывает на существенную разницу в механизме транспорта кислорода через слой $\mathrm{SiO}_{2}$ при окислении кремния в среде кислорода и при окислении кремния под слоем $\mathrm{V}_{2} \mathrm{O}_{5}$. В ряде работ [12-14] исследован процесс ускоренного окисления кремния при температурах 723-973 К в смесях кислород-озон, где присутствует атомарный кислород, возникающий вследствие разложения молекул озона. В работе [12] показано, что при температуре $873 \mathrm{~K}$ в течение 20 мин толщина слоя оксида достигает 7-8нм. Увеличение скорости окисления кремния в среде $\mathrm{O}_{2} / \mathrm{O}_{3}$ связывается с присутствием атомарного кислорода. Из-за малого радиуса атома кислорода его коэффициент диффузии через слой $\mathrm{SiO}_{2}$ существенно больше, чем молекулярного кислорода, что и объясняет увеличение скорости окисления. Однако при окислении в газовой среде при 873-973 К даже в присутствии атомарного кислорода не удается получить оксидный слой толщиной > 15 нм. Увеличение скорости твердофазного окисления кремния под слоем $\mathrm{V}_{2} \mathrm{O}_{5}$ можно объяснить влиянием двух факторов. Прежде всего отметим, что кислород входит в состав $\mathrm{V}_{2} \mathrm{O}_{5}$ в виде атомов. Естественно предположить, что реакция окисления кремния происходит путем перемещения атомов кислорода от $\mathrm{V}_{2} \mathrm{O}_{5}$ к кремнию. Атомарный кислород из-за малых размеров гораздо подвижнее молекулы кислорода, что и обусловливает увеличение коэффициента диффузии кислорода через слой растущего оксида кремния. Вторым фактором, влияющим на скорость окисления, является разница химических потенциалов $(\mu)$ кислорода на внешней поверхности диоксида кремния и слоем на границе $\mathrm{SiO}_{2}-\mathrm{Si}$. В соответствии с законом Фика поток диффундирующих частиц $J$ пропорционален градиенту химического потенциала: $J=D(d \mu / d h)$, где $h-$ толщина оксида кремния, $D-$ коэффициент диффузии. Основной вклад в градиент химического потенциала вносит разность концентраций кислорода на поверхности растущего оксида и в слое вблизи границы $\mathrm{SiO}_{2}-\mathrm{Si}$. В случае окисления из газовой среды концентрация кислорода вблизи внешней поверхности $\mathrm{SiO}_{2}$ равна $\sim 3 \cdot 10^{19} \mathrm{~cm}^{-3}$, в то время как при твердофазном окислении концентрация атомов кислорода, находящегося на поверхности кремния, соответствует концентрации кислорода в $\mathrm{V}_{2} \mathrm{O}_{5}$ и равна $\sim 5 \cdot 10^{22} \mathrm{~cm}^{-3}$. Сравнение концентраций кислорода на поверхности $\mathrm{SiO}_{2}$ показывает, что при твердофазном окислении диффузия кислорода происходит в существенно большем градиенте химического потенциала, что является дополнительным фактором, увеличивающим скорость окисления кремния. Для непрерывного протекания реакции (1) необходимо поддерживать состав пленки $\mathrm{V}_{2} \mathrm{O}_{5}$ постоянным. Спектры комбинационного рассеяния пленки $\mathrm{V}_{2} \mathrm{O}_{5}$ до и после отжига оставались без изменений, поэтому можно сделать вывод, что в процессе реакции $\mathrm{V}_{2} \mathrm{O}_{5}$ сохранял свой химический состав. В работе [14] исследован процесс окисления ванадия в атмосфере кислорода при температуре $873 \mathrm{~K}$ и показано, что при этой температуре величина коэффициента диффузии кислорода в $\mathrm{V}_{2} \mathrm{O}_{5}$ равна $\sim 3 \cdot 10^{-11} \mathrm{~cm}^{2} \cdot \mathrm{c}^{-1}$, т. е. на несколько порядков больше, чем коэффициент диффузии кислорода через пленку оксида кремния. Поэтому расход кислорода из пленки $\mathrm{V}_{2} \mathrm{O}_{5}$ на окисление кремния восполнялся за счет поступления кислорода из газовой фазы.

Поскольку $\mathrm{V}_{2} \mathrm{O}_{5}$ участвует в реакции (1), но не расходуется, можно сделать вывод, что пленка $\mathrm{V}_{2} \mathrm{O}_{5}$ является хемостимулятором окисления кремния и выполняет функцию донора атомарного кислорода. Из-за низких значений коэффициента диффузии кислорода при достижении критической толщины слоя $\mathrm{SiO}_{2}$ скорость окисления кремния становится пренебрежимо малой и рост слоя оксида кремния прекращается.

Количество крупных включений оксида кремния, приходящееся на $1 \mathrm{~cm}^{2}$ поверхности кремния, можно оценить, используя данные электронно-микроскопического анализа поверхности кремния после обработки образца в плавиковой кислоте. На различных участках поверхность кремния площадью $\sim(10-12)$ мкм $^{2}$ содержала от 30 до 100 вогнутых сфероидов, образовавшихся после растворения крупных включений оксида кремния.

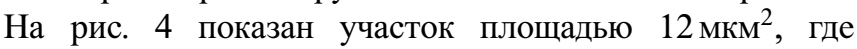
находится $\sim 100$ вогнутых сфероидов. Следовательно, на $1 \mathrm{~cm}^{2}$ поверхности кремния содержится $\sim(2.5-8) \cdot 10^{8}$ вогнутых полостей. Плотность дислокаций в кремнии, использованном в экспериментах, не превышала $10^{2} \mathrm{~cm}^{-2}$, что на несколько порядков меньше плотности сфероидов. Поэтому невозможно объяснить появление глубоких включений оксида кремния ускоренным окислением кремния в местах выхода дислокаций. Как было показано выше (рис. 6), в процессе термических обработок в объеме пластин кремния возникают преципитаты $a-\mathrm{SiO}_{x}$ с характерными размерами от 1 до $3 \mathrm{Hм}$. Этот процесс происходит за счет распада пересыщенного раствора кислорода в случае нагрева при температуpax $>703 \mathrm{~K}$. Концентрация преципитатов $a-\mathrm{SiO}_{x}$ в $\mathrm{Cz}-$ кремнии после отжига при температурах 903-973 K может составлять $\sim\left(10^{10}-10^{11}\right) \mathrm{cm}^{-3}[10,15]$. Процесс образования преципитатов $\mathrm{SiO}_{x}$ в кремнии происходит параллельно твердофазной реакции $\mathrm{V}_{2} \mathrm{O}_{5}$ и кремния. Из-за разности параметров решеток, коэффициентов термического расширения кремния и преципитатов $\mathrm{SiO}_{x}$ возникают деформации, сопровождающиеся большими механическими напряжениями. В результате в кремнии вблизи границы $\mathrm{Si}-\mathrm{V}_{2} \mathrm{O}_{5}$ образуются микроучастки с высокой концентрацией дефектов, где коэффициент диффузии кислорода и скорость реакции (1) существенно больше, чем на остальной поверхности кремния. Эти области являются инициирующими центрами, дополнительно ускоряющими окисление кремния. В результате на границе $\mathrm{Si}-\mathrm{V}_{2} \mathrm{O}_{5}$ образуется неоднородный по толщине слой $\mathrm{SiO}_{2}$ с включениями оксида кремния в кремний глубиной до 400 нм. После удаления слоев $\mathrm{V}_{2} \mathrm{O}_{5}$ и диоксида кремния на поверхности кремния образуется текстура, интенсивно рассеивающая свет в области длин волн 300-550 нм, что может быть использовано при создании эффективных солнечных фотопреобразователей. 
Работа выполнялась по проекту Министерства образования и науки России № 14.607.21.0075 (RFMEFI60714X0075). Электронно-микроскопические исследования проводились с использованием оборудования регионального центра коллективного пользования „Материаловедение и диагностика в передовых технологиях“ при ФТИ им. А.Ф. Иоффе.

\section{Список литературы}

[1] T. Mishina, M. Taguchi, H. Sakata, E. Maruyama. Sol. Energy Mater. Sol. Cells, 95, 18 (2010).

[2] A. Chen, K. Zhu. Solar Energy, 86, 393 (2012).

[3] M. Edwards, S. Bowden, U. Das, M. Burrows. Sol. Energy Mater. Sol. Cells, 92, 1373 (2008).

[4] B. Vallejo, M. Gonzales-Manas, J. Martinez-Lopez, M.A. Caballero. Solar Energy, 81, 565 (2007).

[5] J. Kegela, H. Angermann, U. Stürzebecher, E. Conrad, M. Mews, L. Korte, B. Stegemann. Appl. Surf. Sci., 301, 56 (2014).

[6] M. Moreno, D. Murias, J. Martinez, C. Reyes-Betanzo, A. Torres, R. Ambrosio, P. Rosales, P. Roca i Cabarrocas, M. Escobar. Solar Energy, 101, 182 (2014).

[7] И.Я. Миттова, Е.В. Томина, А.А. Лапенко, Б.В. Сладкопевцев. Наносистемы: физика, химия, математика, 3 (2), 116 (2012).

[8] Термодинамические свойства неорганических веществ. Справочник, под ред. А.П. Зефирова (М., Атомиздат, 1965).

[9] C. Navone, J.P. Pereira-Ramos, R. Baddour-Hadjean, R. Salot. Proc. Intern. Workshop, „Advanced Techniques for Energy Sources Investigation and Testing" (Sofia, Bulgaria, 2004). L5-1.

[10] A. Borghesi, B. Pivac, A. Sassella, A. Stella. J. Appl. Phys. 77, 4169 (1995).

[11] А.И. Курносов, В.В. Юдин. Технология производства полупроводниковых приборов и интегральных микросхем (М., Высш. шк., 1986) гл. 7, с. 118.

[12] A. Kazor, R. Gwilliam, Ian W. Boyd. Appl. Phys. Lett. 65, 412 (1994).

[13] Zh. Cui, J.M. Madsen, Ch.G. Takoudis. J. Appl. Phys. 87, 8181 (2000).

[14] J.R. Wilson, M.E. Levis. Nature, 206, 1350 (1965).

[15] J.D. Murphy, R.E. McGuire, K. Bothe, V.V. Voronkov, R.J. Falster. Sol. Energy Mater. Sol. Cells, 120, 402 (2014).

\section{Texture of monocrystalline silicon surface} oxidized under thin $\mathrm{V}_{2} \mathrm{O}_{5}$ layer

\author{
S.E. Nikitin' ${ }^{1}$, V.N. Verbitskiy ${ }^{1}$, A.V. Nashchekin ${ }^{1}$, \\ I.N. Trapeznikova ${ }^{1}$, A.V. Bobyl ${ }^{\mathbf{1}}$, E.E. Terukova ${ }^{\mathbf{1 , 2}}$ \\ ${ }^{1}$ loffe Institute, \\ 194021 St. Petersburg, Russia \\ ${ }^{2}$ Research and development center for thin-film \\ technologies in energetics, \\ 194064 St. Petersburg, Russia
}

\begin{abstract}
Process of texturing a monocrystalline silicon surface oxidized under thin $\mathrm{V}_{2} \mathrm{O}_{5}$ layer is investigated. Intensive oxidation of silicon at the $\mathrm{Si}-\mathrm{V}_{2} \mathrm{O}_{5}$ interface appeared at $903 \mathrm{~K}$ that is by $200 \mathrm{~K}$ lower than at thermal oxidation of silicon in oxygen atmosphere. Formation of silicon dioxide layer with thickness $30-50 \mathrm{~nm}$ and inclusions of $\mathrm{SiO}_{2}$ into silicon with depth to $400 \mathrm{~nm}$ was registered at the interface between $\mathrm{Si}$ and $\mathrm{V}_{2} \mathrm{O}_{5}$. Value of the diffusion coefficient of atomic oxygen through silicon dioxide layer attained $2 \cdot 10^{-15} \mathrm{~cm}^{2} \cdot \mathrm{s}^{-1}$ at $903 \mathrm{~K}$. The model of low-temperature oxidation of silicon based on atomic oxygen diffusion from $\mathrm{V}_{2} \mathrm{O}_{5}$ to silicon through $\mathrm{SiO}_{2}$ layer and formation of $\mathrm{SiO}_{x}$ precipitates in silicon is suggested. After removal of $\mathrm{V}_{2} \mathrm{O}_{5}$ and silicon dioxide layers on the silicon surface texture is appeared. This texture scatteres light intensively in the spectral range $300-550 \mathrm{~nm}$ which is important for texturing front and rear surface of photovoltaic solar cells.
\end{abstract}

